\title{
Composition of volcanic gases emitted during repeating Vulcanian eruption stage of Shinmoedake, Kirishima volcano, Japan
}

\author{
H. Shinohara \\ Geological Survey of Japan, AIST, Central 7, 1-1-1 Higashi, Tsukuba, Ibaraki 305-8567, Japan \\ (Received August 15, 2012; Revised November 13, 2012; Accepted November 14, 2012; Online published July 8, 2013)
}

\begin{abstract}
Volcanic gas compositions of Shinmoedake, Kirishima volcano, Japan were measured by Multi-GAS during the persistent degassing period with repeating Vulcanian eruptions from March 2011 to March 2012. In order to avoid risks due to eruptions, the measurements were performed with the Unmanned Aerial Vehicles (UAV) that fly through the plume with the Multi-GAS and by an automatic Multi-GAS monitoring station installed 5 $\mathrm{km}$ away from the summit. Based on the UAV measurements on May 18, 2011, most of the major volcanic gas components were quantified as $\mathrm{CO}_{2} / \mathrm{SO}_{2}=8, \mathrm{SO}_{2} / \mathrm{H}_{2} \mathrm{~S}=0.8, \mathrm{H}_{2} \mathrm{O} / \mathrm{CO}_{2}=70$ and $\mathrm{H}_{2} / \mathrm{SO}_{2}=0.03$ (mol ratio), and the $\mathrm{SO}_{2} / \mathrm{H}_{2} \mathrm{~S}$ ratio of the plume was quantified as 8 on March 15, 2011. The Multi-GAS monitoring station occasionally detected a dilute plume with an $\mathrm{SO}_{2} / \mathrm{H}_{2} \mathrm{~S}$ ratio ranging from 0.8 to 3.3 from April 2011 to March 2012. The decrease of the $\mathrm{SO}_{2} / \mathrm{H}_{2} \mathrm{~S}$ ratio from March 15, 2011, to May 18, 2011, is interpreted as the result of a ten times increase of the degassing pressure. Based on the $\mathrm{SO}_{2}$ fluxes and the gas compositions, the conduit magma convection is considered to be the gas supply mechanism at the Shinmoedake, and the degassing pressure changes are attributed to the change of depth of the convecting magma column top.
\end{abstract}

Key words: Volcanic gas composition, Multi-GAS, Shinmoedake, UAV, magma convection, Kirishima volcano, degassing.

\section{Introduction}

Volcanic gas composition is controlled by volatile contents in magmas and their degassing condition, and is an important indicator of magmatic plumbing and degassing conditions that help to monitor volcanic activities. Classical studies of volcanic gases by direct sampling and analysis can be applied only for accessible fumaroles, and studies of large-scale degassing activities were quite limited. The development of instrumental techniques has enabled the measurement of volcanic gas composition of large-scale degassing by measuring the volcanic plume. Conventional manned aircraft can transport fairly large instruments and have been applied to measure the volcanic plume composition (Gerlach et al., 1997; Shinohara et al., 2003a). The application of manned aircraft, however, is limited to quiescent states of volcanoes to avoid risks to the operators. FTIR remote-sensing has enabled composition measurement of eruptive degassing and has revealed variations of the gas composition during lava fountain, lava effusion and Strombolian eruptions (Allard et al., 2005; Oppenheimer et al., 2006). Continuous monitoring of the plume gas composition by the Multi-GAS has also been applied to detect gas composition variation prior to an eruption (Aiuppa et al., 2009). The application of FT-IR and the Multi-GAS is also limited by accessibility to the degassing vent.

Unmanned aerial vehicles (UAV) commonly are small

Copyright (C) The Society of Geomagnetism and Earth, Planetary and Space Sciences (SGEPSS); The Seismological Society of Japan; The Volcanological Society of Japan; The Geodetic Society of Japan; The Japanese Society for Planetary Sciences; TERRAPUB. aircrafts with payloads ranging from a few to tens of kilograms and are widely used in atmospheric science studies because of their low cost operation and flight planning flexibility (Lin, 2006; Watai et al., 2006). In volcanology, the UAV has another important advantage in that they can work even in high-risk areas, such as near a vent with frequent explosions. This advantage is important for a volcanic plume study, because measurements near a vent are necessary to reduce the error due to dilution of the plume with distance. The first report of a UAV application to a volcanic plume study was given by McGonigle et al. (2008), who conducted $\mathrm{SO}_{2}$ flux measurements with a compact UV spectrometer and measured the $\mathrm{CO}_{2} / \mathrm{SO}_{2}$ ratio with a simple Multi-GAS system mounted on a small unmanned helicopter at La Fossa crater, Vulcano, Italy. Although the surveyed area was not under risk during the operation, they demonstrated the capability of the UAV for volcanic plume measurements under conditions of risk.

In this report, we present the results of composition measurements of volcanic plumes by the application of a UAV during a persistent degassing stage at Shinmoedake, Kirishima volcano, Japan. Since Vulcanian eruptions were repeated during this study, an area of $4 \mathrm{~km}$ from the summit was closed, even for manned aircrafts, and a UAV was necessary to perform near vent plume measurement. We also report the results of volcanic plume composition monitoring with a Multi-GAS automatic station installed $5 \mathrm{~km}$ from the summit, where dilute plumes occasionally reached. Based on the results of these measurements, we estimate composition variation with time and discuss its origin. 


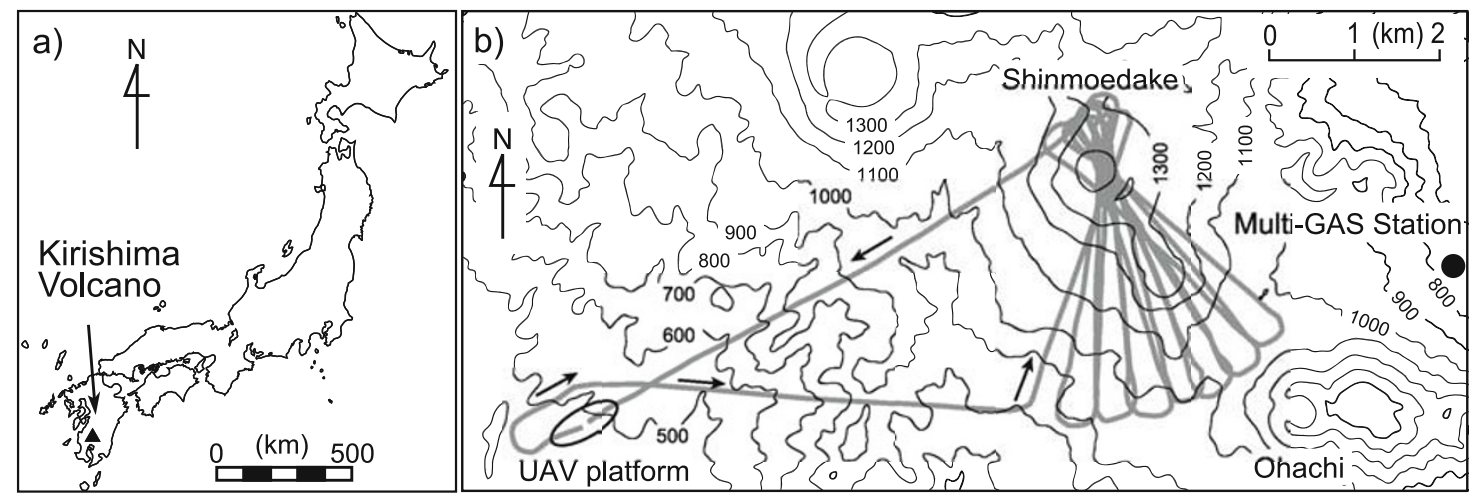

Fig. 1. Map of Kirishima volcano. (a) Location of Kirishima volcano in Japan. (b) Detailed map around the Shinmoedake eruptive center. An example of the UAV flight track of the second flight on May 18, 2011, is shown by the grey curve. The volcanic plumes were mostly detected just above the summit crater.

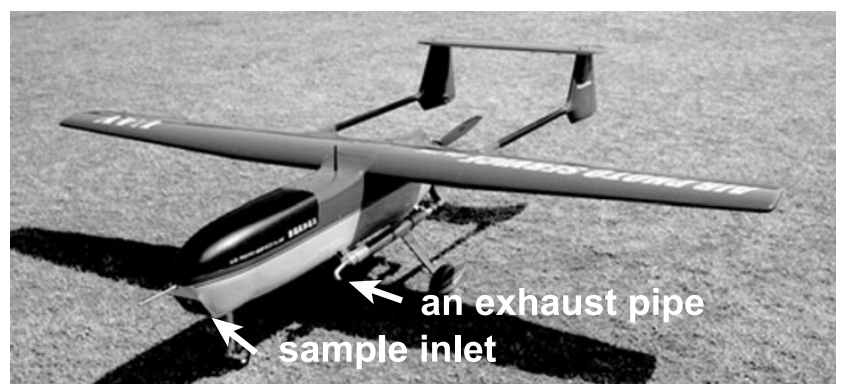

Fig. 2. Photo of the UAV (a fixed wind APS-type 3). Photo was taken by the Air Photo Service Co., Japan. The length and width of the UAV are 220 and $280 \mathrm{~cm}$. The sample inlet is located at the front and the exhaust pipes are located at the side of the UAV.

\section{Shinmoedake Volcano}

Shinmoedake volcano is one of the numerous active volcanic peaks of the Kirishima volcanic complex at the southern part of Kyushu Island, Japan (Fig. 1). The major magmatic eruption of Shinmoedake volcano occurred about 300 years ago and later only minor phreatic eruptions have occurred occasionally (Imura and Kobayashi, 2001). Degassing activity was quite minor before the 2011 eruption. The 2011 eruptive activity started with a minor phreatomagmatic eruption on January 19, 2011, which was followed by sub-Plinian eruptions on January 26-27, 2011. The subPlinian eruptions produced columns which reached about $7 \mathrm{~km}$ above the volcano and ejected about $3 \times 10^{7}$ tons of pyroclasts (Furukawa et al., 2012). Immediately after the explosive eruptions, lava effused out and, within a few days, filled the summit crater with a volume of $2 \times 10^{7} \mathrm{~m}^{3}$ (Miyagi, 2011). Intermittent Vulcanian eruptions started after the lava effusion. The intensity and frequency of the Vulcanian eruptions were large at the beginning in February and decreased with time. Eruptive activity was not observed after the most recent eruption in September but significant volcanic gas emission still continues (JMA, Monthly Report).

Before the eruptive activity started in January 2011, degassing activity was not significant at the Kirishima volcano. The significant degassing plume, which could be traced further than $10 \mathrm{~km}$ from the summit, was recognized on January 22, 2011, four days before the sub-Plinian eruption (Kinoshita et al., 2011), but $\mathrm{SO}_{2}$ flux measurement was not carried out before the eruption. The early $\mathrm{SO}_{2}$ flux measurements were carried out during pause periods of the sub-Plinian eruptions and resulted in quite large fluxes of $>10 \mathrm{kt} / \mathrm{d}$ (Mori and Kato, 2013). The $\mathrm{SO}_{2}$ flux rapidly decreased after the lava effusion and reached less than 1,000 $\mathrm{t} / \mathrm{d}$ in March. From March 2011 to the present, the $\mathrm{SO}_{2}$ flux varies between 100 and $400 \mathrm{t} / \mathrm{d}$.

\section{Method}

The UAV was a fixed wing APS-Type 3 (Fuji Imvac Co., Japan) operated by the Air Photo Service Co. Japan (Fig. 2). The length and width of the UAV are 220 and 280 $\mathrm{cm}$, respectively, and it weighs $15 \mathrm{~kg}$ without payloads and fuels. The maximum payload is about $3 \mathrm{~kg}$ for a 1 -h flight up to a 2000-m altitude and the payload room dimensions are $20 \times 40 \times 18 \mathrm{~cm}$ (width $\times$ length $\times$ height). The UAV is automatically navigated by a preset flight path with GPS except during takeoff and landing. The UAV can communicate with a base station to monitor its real time position up to several kilometers and the flight program can be remotely cancelled in case of an emergency such as volcanic explosions. The ceiling air speed ranges from 100 to $220 \mathrm{~km} / \mathrm{h}$.

A Multi-GAS (Aiuppa et al., 2005; Shinohara, 2005) was modified to fit the limited volume and weight capacity of the UAV payload space. The Multi-GAS consists of a nondispersive infrared $\mathrm{CO}_{2}-\mathrm{H}_{2} \mathrm{O}$ analyzer (LI-840, LI-COR, Inc., Lincoln, USA), $\mathrm{SO}_{2}$ and $\mathrm{H}_{2} \mathrm{~S}$ electrochemical sensors (KTS-512 and KHS-5TA, respectively, Komyo Rikagaku K.K., Kawasaki, Japan), and an $\mathrm{H}_{2}$ semi-conductor sensor (Model GM12s, Sensor Tech K.K., Rittou, Japan). Filter- 




Fig. 3. Variation of volcanic gas components concentrations in the volcanic plume obtained by UAV measurement. The figure shows a part of the results obtained during the second flight on May 18, 2011. The slight differences of the peak positions are due to the different time lag of each sensor. The $\mathrm{H}_{2}$ sensor shows a long tailing due to the slow response of the sensor particularly in the low concentration range.

type scrubbers for $\mathrm{H}_{2} \mathrm{~S}$ and $\mathrm{SO}_{2}$ were placed in front of the KTS-512 and KHS-5TA sensors, respectively, to reduce cross-sensitivity of these sensors (Shinohara et al., 2011). The power was supplied by a small $12 \mathrm{~V} 1.5$ Ah Lithium Ion Polymer battery, which can run the system for a few hours and the results are recorded every second by a data logger (NR-1000, Keyence Co. Japan). The gases are pumped at a rate of $1 \mathrm{l} / \mathrm{min}$ from an air inlet at the front of the UAV into the Multi-GAS through Teflon tubing (Fig. 2).

A Multi-GAS was installed about $5 \mathrm{~km}$ southeast of the Shinmoedake volcano to monitor the variation of the volcanic gas compositions (Fig. 1(b)). The Multi-GAS consists of the same set of gas sensors listed above. The $\mathrm{H}_{2} \mathrm{~S}$ sensor was not equipped with an $\mathrm{SO}_{2}$ scrubber, because the capacity of an $\mathrm{SO}_{2}$ scrubber is small and it can be saturated after a long monitoring period. The concentration of $\mathrm{H}_{2} \mathrm{~S}$ is calculated by subtracting the $\mathrm{SO}_{2}$ contribution to the $\mathrm{H}_{2} \mathrm{~S}$ sensor, based on the $\mathrm{SO}_{2}$ concentration measured by the $\mathrm{SO}_{2}$ sensor and the cross sensitivity to $\mathrm{SO}_{2}$ calibrated in the laboratory. In order to save the power consumption and extend the lifetime of the sensors, the Multi-GAS ran only for $1.5 \mathrm{~h}$ everyday at about noon. The data were transmitted to a data server by a mobile phone and then collected through the Internet. The system was powered by a lead battery charged by solar panels.

\section{Results}

\subsection{UAV plume measurements}

The plume measurements by the UAV were performed on March 15 and May 18, 2011. The UAV was launched from a campground $7 \mathrm{~km}$ southwest from the Shinmoedake (Fig. 1(b)). Three flights of 60 min duration were conducted each day. Flight courses were variable taking into consideration wind direction and plume height estimated by visual observation from the base station and web cameras. The wind directions were also determined by $\mathrm{SO}_{2}$ tracking with
COMPUSS (Mori et al., 2007) prior to the UAV flights (T. Mori, pers. comm.). The degassing activity was not intense with 500 and 200 ton/day of $\mathrm{SO}_{2}$ on March 15 and May 18, 2011, respectively (Mori and Kato, 2013). Figure 1(b) shows an example of the track of the second flight on May 18, 2011. With an SSE wind, the UAV scanned between the summit and the downwind of south to southeast at 1600and 1800-m altitudes.

The volcanic plume was detected as $\mathrm{SO}_{2}$ peaks during one flight on March 15 and three flights on May 18. The maximum $\mathrm{SO}_{2}$ concentrations were 0.7 and $2.5 \mathrm{ppm}$ on March 15 and May 18, respectively. An example of the Multi-GAS data of the second flight on May 15 is shown in Fig. 3. The $\mathrm{SO}_{2}, \mathrm{H}_{2} \mathrm{~S}$ and $\mathrm{CO}_{2}$ peaks are perfectly coincident with slight differences of onset time likely due to the difference of sensor response times. Increases of $\mathrm{H}_{2}$ and $\mathrm{H}_{2} \mathrm{O}$ concentrations and temperature also coincide with other peaks but the shapes of the peaks are not quite similar. Hydrogen peaks have longer tails most likely due to slow sensor response at the low hydrogen concentration range (Shinohara et al., 2011). Variations of water concentration and temperature at the peaks are less clear, likely because of a larger background variation. Composition of the volcanic gases on May 18, 2011, is estimated based on the correlation plot of the Multi-GAS data (Fig. 4). The estimated molal ratios are $\mathrm{CO}_{2} / \mathrm{SO}_{2}=8 \pm 1, \mathrm{SO}_{2} / \mathrm{H}_{2} \mathrm{~S}=0.8 \pm 0.1$, $\mathrm{H}_{2} \mathrm{O} / \mathrm{CO}_{2}=70 \pm 20$ and $\mathrm{H}_{2} / \mathrm{SO}_{2}=0.03 \pm 0.01$, that corresponds to a total composition of $\mathrm{H}_{2} \mathrm{O}=98, \mathrm{CO}_{2}=1.4$, $\mathrm{SO}_{2}=0.18, \mathrm{H}_{2} \mathrm{~S}=0.22$ and $\mathrm{H}_{2}=0.005 \mathrm{~mol} \%$. The UAV could reach only a dilute plume with a maximum $\mathrm{SO}_{2}$ concentration of $0.7 \mathrm{ppm}$ on March 15, and a quantitative ratio estimate was possible only for $\mathrm{SO}_{2} / \mathrm{H}_{2} \mathrm{~S}$, which was $8 \pm 1.5$.

\subsection{Monitoring station results}

The monitoring station was installed on April 12, 2011, and the measurement was repeated daily since then. During 

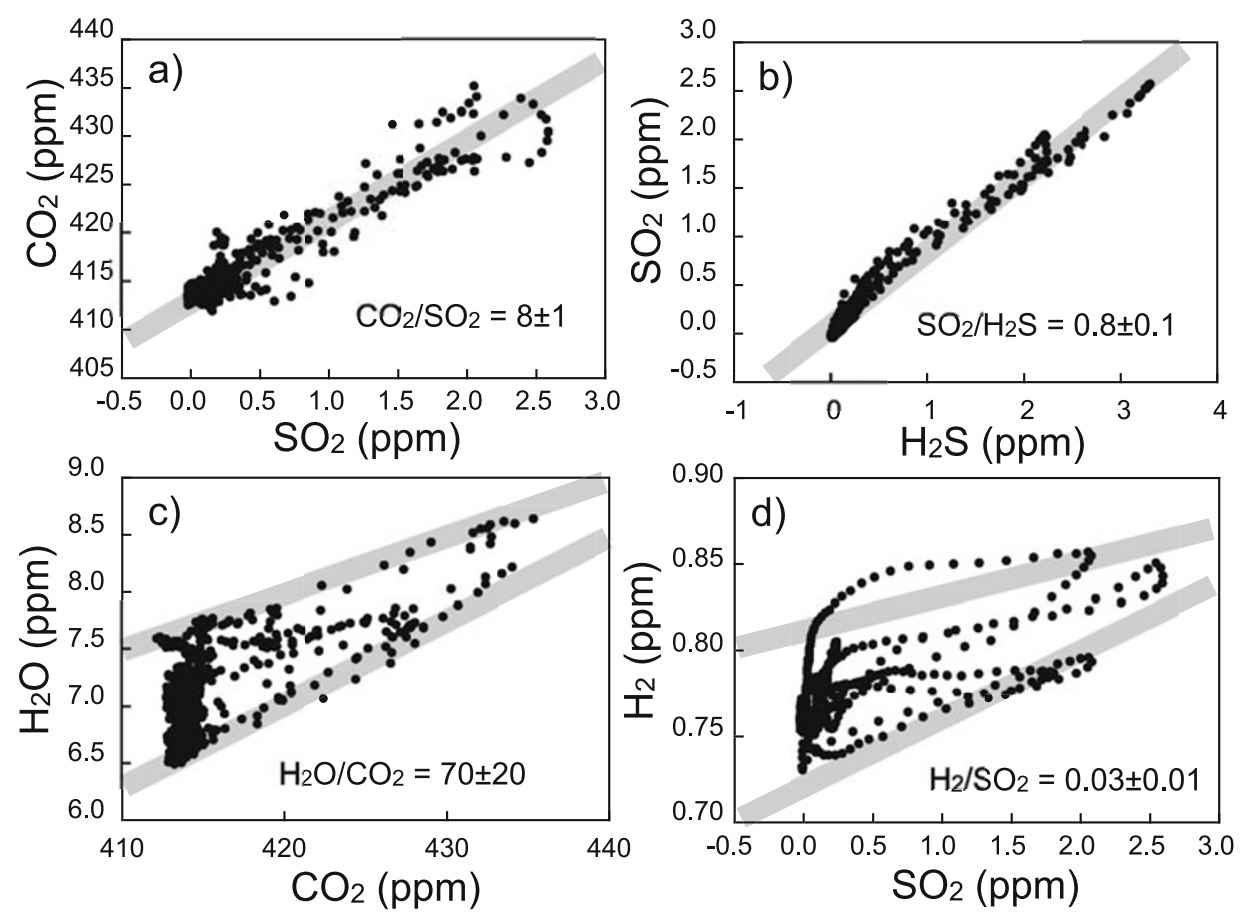

Fig. 4. Scatter plots showing correlation of concentrations of different species. The same dataset as on Fig. 3 are plotted. The data are plotted after correcting the sensor time-lag differences shown on Fig. 3. Grey thick lines are regression lines whose slope and error are also given in the figures. Figures (c) and (d) show a large scatter and two regression lines are drawn to cover the range of the estimated ratios.

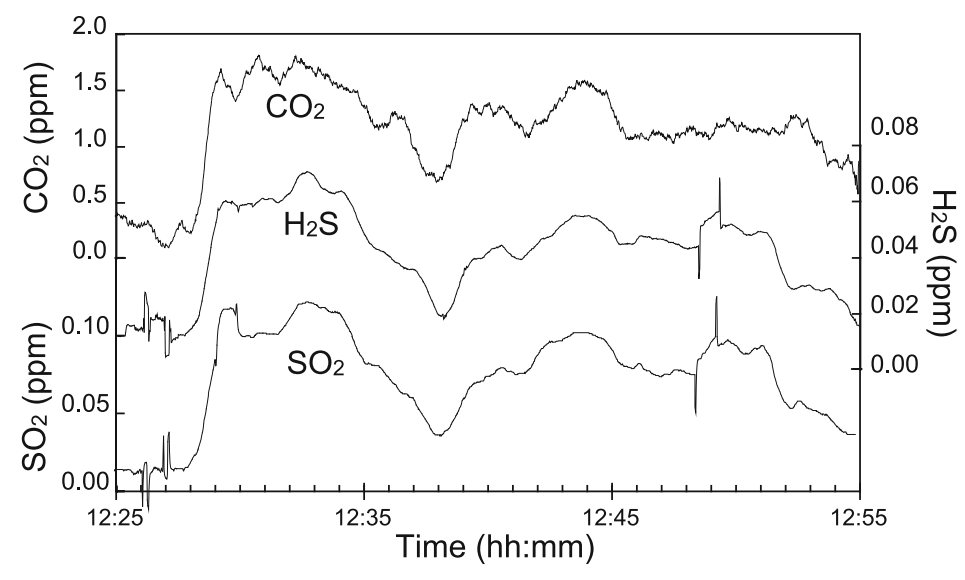

Fig. 5. Variation of volcanic gas component concentration obtained by the Multi-GAS monitoring station on February 19, 2012. Concentrations are plotted after subtraction of the background concentrations. Drifts of the background concentrations on the $\mathrm{SO}_{2}$ and $\mathrm{H}_{2} \mathrm{~S}$ sensors are also corrected by assuming a linear variation of the zero point with time.

about one year of operation, parallel variations of $\mathrm{SO}_{2}$ and $\mathrm{H}_{2} \mathrm{~S}$ concentrations were observed 15 times (Fig. 5). The low frequency of the volcanic plume arrival to the monitoring site is due to its distant location and the lower altitude than the summit. The detected concentrations are low with maximum $\mathrm{SO}_{2}$ concentrations ranging from 0.04 to $0.22 \mathrm{ppm}$ (Table 1). As the noise and background level of the $\mathrm{SO}_{2}$ and $\mathrm{H}_{2} \mathrm{~S}$ sensors are quite small, $\mathrm{SO}_{2} / \mathrm{H}_{2} \mathrm{~S}$ ratios are well quantified even for these low concentration peaks (Fig. 6). The large background variation of the atmospheric $\mathrm{CO}_{2}$ concentration commonly veils the variation due to the volcanic plume, but the parallel variation of $\mathrm{CO}_{2}$, $\mathrm{SO}_{2}$ and $\mathrm{H}_{2} \mathrm{~S}$ concentrations was also obtained three times, and $\mathrm{CO}_{2} / \mathrm{SO}_{2}$ ratios were quantified with reasonable precision (Table 1; Fig. 6).
The $\mathrm{SO}_{2} / \mathrm{H}_{2} \mathrm{~S}$ ratios obtained by the monitoring station range from 0.8 to 3.3 (Table 1). The ratios obtained with short intervals agree well. For examples, the ratios obtained on June 17 and 20, 2011, are 1.6 and 2.0, and those obtained on February 1, 2 and 19, 2012, are 2.0, 2.0 and 1.8, respectively. In contrast, a gradual change of the ratio was also observed in a long-time range of a few months. The $\mathrm{SO}_{2} / \mathrm{H}_{2} \mathrm{~S}$ ratio of 0.8 obtained on May 18, 2011, by the UAV measurement agree with the ratio obtained on May 12, 2011, by the monitoring station. This agreement indicates the good precision of the measurements and implies that the gradual variation in the long-time range is likely to be the true temporal variation. The $\mathrm{SO}_{2} / \mathrm{H}_{2} \mathrm{~S}$ ratio obtained on March 15,2011 , by the UAV measurement was 10 -much larger than the later values. Compilation of the UAV and the mon- 

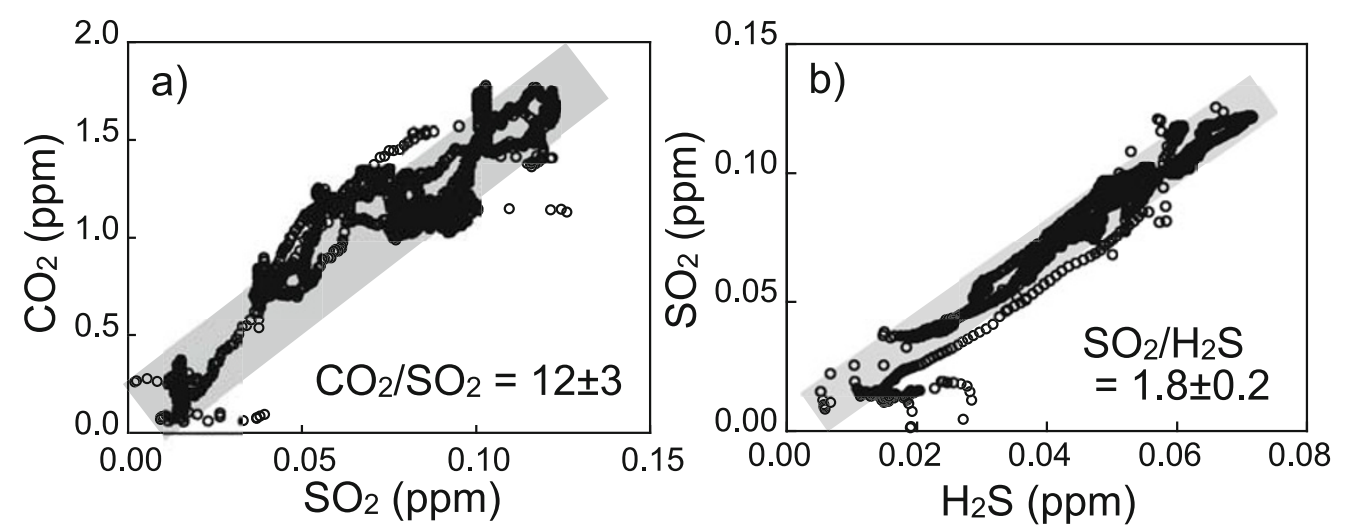

Fig. 6. Scatter plots showing the correlation of $\mathrm{CO}_{2}, \mathrm{SO}_{2}$ and $\mathrm{H}_{2} \mathrm{~S}$. The same dataset as on Fig. 5 are plotted after correction of the sensor time lag. Grey thick lines are regression lines whose slope and error are also given.

Table 1. Results of the Multi-GAS remote station.

\begin{tabular}{|c|c|c|c|c|c|}
\hline \multirow{2}{*}{$\begin{array}{c}\text { Date } \\
\text { (yy.mm.dd) }\end{array}$} & \multicolumn{3}{|c|}{ max. $\mathrm{SO}_{2} \mathrm{SO}_{2} / \mathrm{H}_{2} \mathrm{~S}$ ratio } & \multicolumn{2}{|c|}{$\mathrm{CO}_{2} / \mathrm{SO}_{2}$ ratio } \\
\hline & (ppm) & & error & & \pm error \\
\hline $11 / 4 / 28$ & 0.3 & 3 & 0.3 & - & - \\
\hline $11 / 5 / 12$ & 0.1 & 0.8 & 0.4 & ـ & ـ \\
\hline $11 / 6 / 17$ & 0.2 & 1.6 & 0.2 & - & - \\
\hline $11 / 6 / 20$ & 0.08 & 2 & 1.5 & - & - \\
\hline $11 / 7 / 1$ & 0.3 & 1.4 & 0.2 & - & ـ \\
\hline $11 / 8 / 19$ & 0.04 & 1.3 & 0.6 & - & - \\
\hline $11 / 9 / 30$ & 0.5 & 2.3 & 0.2 & - & - \\
\hline $11 / 10 / 22$ & 0.4 & 3.3 & 0.3 & - & - \\
\hline $11 / 11 / 23$ & 0.16 & 1.4 & 0.3 & - & - \\
\hline $11 / 12 / 3$ & 0.15 & 1.7 & 0.2 & - & - \\
\hline $12 / 1 / 6$ & 0.22 & 1.9 & 0.2 & 12 & 3 \\
\hline $12 / 2 / 1$ & 0.08 & 2 & 0.4 & - & - \\
\hline $12 / 2 / 2$ & 0.12 & 2 & 0.2 & 12 & 6 \\
\hline $12 / 2 / 19$ & 0.12 & 1.8 & 0.2 & 12 & 3 \\
\hline $12 / 3 / 6$ & 0.02 & 2 & 1.5 & - & - \\
\hline
\end{tabular}

itoring station results shows that the $\mathrm{SO}_{2} / \mathrm{H}_{2} \mathrm{~S}$ ratios decreased from 10 in March to 0.8 in May, then stayed around two with a small and gradual variation (Fig. 7). The same $\mathrm{CO}_{2} / \mathrm{SO}_{2}$ ratios of 12 were estimated in January and February 2012 suggesting the reliability of the estimate. This ratio agrees with the estimate of 8 obtained by the UAV measurement in May 2011 almost within the error, suggesting a constant $\mathrm{CO}_{2} / \mathrm{SO}_{2}$ ratio after May 2011.

\section{Discussion}

\subsection{Chemical composition}

The Shimoedake volcanic gas measured on May 18, 2012 is sulfur-poor compared with volcanic gas compositions of persistently degassing volcanoes such as the Miyakejima, Kudryavy and Satsuma-Iwojima volcanoes (Taran et al., 1995; Shinohara et al., 2002, 2003b; Fig. 8), and is closer to the composition of high-temperature gases discharged during post-dome forming eruption activity such as at the Usu or Showa-Shinzan volcanoes (Mizutani and Sugiura, 1982; Giggenbach and Matsuo, 1991). The post-dome gases are characterized by low-S and high- $\mathrm{H}_{2} \mathrm{O}$ contents, that are likely due to gas discharge from already mostly degassed magma during the dome emplacement, and contam- ination of meteoric water heated by the dome (Symonds et al., 1996). Since a large volume of lava is accumulated in the summit crater, the composition similarity suggests that the volcanic gases are exsolved from the lava. The volcanic gas flux, however, was large at Shinmoedake and the large emission is less likely to be derived from already degassed lavas. The $\mathrm{SO}_{2}$ flux ranges from 100 to $400 \mathrm{t} / \mathrm{d}$ even after the initial high flux stage in January-February 2011 (Mori and Kato, 2013). Assuming that the average $\mathrm{SO}_{2}$ flux during one year after March 2011 is $200 \mathrm{t} / \mathrm{d}$, we can estimate the total amount of the emitted $\mathrm{SO}_{2}$ gas as $7 \times 10^{4} \mathrm{t}$. Since similar $\mathrm{CO}_{2} / \mathrm{SO}_{2}$ ratios were observed, even in March 2012 after one year of the intensive degassing, we assume that the volcanic gases were supplied by the same mechanism during this stage. Based on a petrological modeling of magma mixing and melt inclusion analyses, Saito et al. (2011) estimated the original sulfur content of the Shimoedake magma to be about $500 \mathrm{ppm}$. In order to supply $7 \times 10^{4} \mathrm{t}$ of $\mathrm{SO}_{2}$, the fresh magma of $7 \times 10^{7} \mathrm{t}\left(3 \times 10^{7} \mathrm{~m}^{3}\right)$ needs to be degassed. This magma volume is larger than that of the lava accumulated in the summit crater $\left(2 \times 10^{7} \mathrm{~m}^{3}\right.$; Miyagi, 2011), and the large amount of $\mathrm{SO}_{2}$ cannot be supplied from the lava already emplaced in the summit crater in January-February, 2011.

The long-term stable degassing with a large emission rate is characteristic of persistent degassing, which is caused by conduit magma convection (Shinohara, 2008). Considering the large magma degassing rate, the conduit magma convection is the likely mechanism of the degassing at Shinmoedake after the lava effusion. The Shinmoedake volcanic gas composition, however, is quite S-poor compared with other persistently degassing volcanoes at subduction zones (Fig. 8). Melt inclusion analyses suggests that the $\mathrm{H}_{2} \mathrm{O}$ and $\mathrm{S}$ contents of the bulk magma are about $2 \mathrm{wt} . \%$ and 500 ppm (Saito et al., 2011), implying that the $\mathrm{H}_{2} \mathrm{O} / \mathrm{S}$ mol ratio of the bulk magma is 70, which is similar to other persistently degassing volcanoes, such as the Satsuma-Iwojima and Miyakejima volcanoes (Saito et al., 2001, 2010). The S-poor volcanic gas composition of the Shinmoedake can be due to high-pressure degassing. Based on empirically estimated gas solubility, Giggenbach (1996) modeled the evolution of the gas composition with degassing. The model suggests that a shallow degassing results in a S-rich gas 


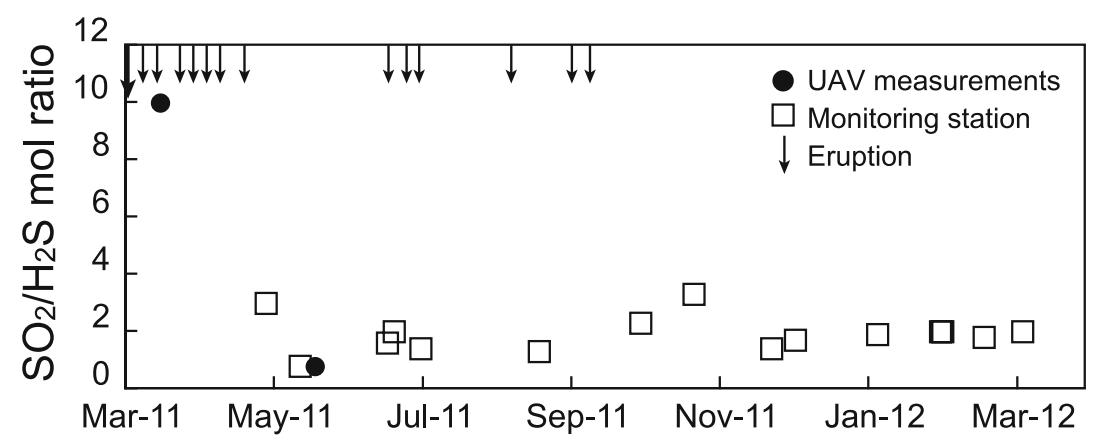

Fig. 7. Variation of the $\mathrm{SO}_{2} / \mathrm{H}_{2} \mathrm{~S}$ ratio. Closed circles are the results of the UAV measurement and open squares are obtained by the Multi-GAS monitoring station. Arrows indicate the occurrence of eruption.



Fig. 8. Relative concentrations of $\mathrm{CO}_{2}, \mathrm{H}_{2} \mathrm{O}$ and $\mathrm{S}_{t}$ of the Shinmoedake volcanic gas. $\mathrm{S}_{t}$ is the total sulfur $\left(\mathrm{SO}_{2}+\mathrm{H}_{2} \mathrm{~S}\right)$. Hexagons denote the compositions of volcanic gases in the literature; SS: Showa-Shinzan (Mizutani and Sugiura, 1982), US: Usu (Giggenbach and Matsuo, 1991), MI: Miyakejima (Shinohara et al., 2003b), SI: Satsuma-Iwojima (Shinohara et al., 2002), KU: Kudryavy (Taran et al., 1995). The arrows indicate the composition trend by degassing at increasing pressure (Giggenbach, 1996).

and the composition becomes S-poor with increasing pressure, then becomes also $\mathrm{H}_{2} \mathrm{O}$-poor with further pressure increase (Fig. 8). This degassing trend qualitatively agrees with the results of recent experimental work by Lense et al. (2011) for basaltic magmas. This degassing trend suggests that the composition difference between the volcanic gases of the Shinmoedake and other persistently degassing volcanoes can be caused by higher pressure degassing at the Shinmoedake than at other volcanoes. The quantitative modeling of the gas composition evolution, however, is still not possible because of the lack of the experimental sulfur partitioning coefficient; in particular, with silicic magmas at low pressure ranges (Webster and Botcharnikov, 2011). The $\mathrm{H}_{2} \mathrm{O}$-rich composition of the Shimoedake gases can also be due to the incorporation of meteoric water heated by the lavas in the crater.

Based on the calculated volcanic gas composition $\left(\mathrm{H}_{2} \mathrm{O}\right.$, $\mathrm{SO}_{2}, \mathrm{H}_{2} \mathrm{~S}$ and $\mathrm{H}_{2} \mathrm{~mol} \%$ ), an apparent equilibrium temperature (AET) can be calculated for the following reaction (Matsuo, 1960; Ohba et al., 1994):

$$
\mathrm{H}_{2} \mathrm{~S}+2 \mathrm{H}_{2} \mathrm{O}=3 \mathrm{H}_{2}+\mathrm{SO}_{2} \text {. }
$$

The equilibrium constant of this reaction is given as follows:

$$
K_{(1)}(T)=\frac{f_{\mathrm{SO}_{2}} \cdot f_{\mathrm{H}_{2}}^{3}}{f_{\mathrm{H}_{2} \mathrm{~S}} \cdot f_{\mathrm{H}_{2} \mathrm{O}}^{2}} \approx \frac{X_{\mathrm{SO}_{2}} \cdot X_{\mathrm{H}_{2}}^{3}}{X_{\mathrm{H}_{2} \mathrm{~S}} \cdot X_{\mathrm{H}_{2} \mathrm{O}}^{2}} \cdot P_{t},
$$

where $K$ is the equilibrium constant, $f$ is the fugacity, $X$ is the mole fraction and $P_{t}$ is the total pressure. The AET is calculated at a total pressure of $0.1 \mathrm{MPa}$. The calculated AET is $394^{\circ} \mathrm{C}$, which is reasonable as the gases were discharged from accumulated lava whose surface was already cooled and solidified.

\subsection{Composition variation}

Variation of the $\mathrm{SO}_{2} / \mathrm{H}_{2} \mathrm{~S}$ ratios was monitored for about one year (Fig. 7). The ratio decreased from 8 on March 15, 2011 , to 0.8 on May 18, 2011, then stayed between 0.8 and 3.3 with gradual fluctuation. In a gas phase, the $\mathrm{SO}_{2} / \mathrm{H}_{2} \mathrm{~S}$ ratio changes by reaction (1), whose equilibrium constant is given by the Eq. (2). If the $\mathrm{H}_{2} / \mathrm{H}_{2} \mathrm{O}$ ratio, therefore the oxygen fugacity, is constant in the gas phase, a decrease of the $\mathrm{SO}_{2} / \mathrm{H}_{2} \mathrm{~S}$ ratio can be caused by a temperature decrease. Hydrogen, however, is a minor species compared 
with $\mathrm{SO}_{2}$ and $\mathrm{H}_{2} \mathrm{~S}$, and the $\mathrm{H}_{2} / \mathrm{H}_{2} \mathrm{O}$ ratio commonly decreases with temperature as a result of reaction (1) under a constant $\mathrm{SO}_{2} / \mathrm{H}_{2} \mathrm{~S}$ ratio (gas buffer; Giggenbach, 1987). The $\mathrm{H}_{2} / \mathrm{H}_{2} \mathrm{O}$ ratio of the Shimoedake gas is $5 \times 10^{-5}$, that is three orders of magnitude lower than that controlled by a QFM buffer, a common rock buffer, and it is unlikely that the $\mathrm{SO}_{2} / \mathrm{H}_{2} \mathrm{~S}$ decrease is caused by a temperature decrease under a constant $\mathrm{H}_{2} / \mathrm{H}_{2} \mathrm{O}$ ratio. A pressure increase at a constant temperature and the $\mathrm{H}_{2} / \mathrm{H}_{2} \mathrm{O}$ ratio results in the $\mathrm{SO}_{2} / \mathrm{H}_{2} \mathrm{~S}$ ratio increase (Eq. (2)). The temperature and the oxygen fugacity is likely to be constant at the magma degassing condition, whereas the pressure can be variable. The ten times decrease of the ratio can be caused by a ten times increase of the degassing pressure. The gradual variation of the $\mathrm{SO}_{2} / \mathrm{H}_{2} \mathrm{~S}$ ratios between 0.8 and 3.3 can be similarly caused by a variation of the degassing pressure by four times. The degassing pressure increase coincides with the high $\mathrm{CO}_{2} / \mathrm{SO}_{2}$ ratio measured on May 18, 2011, which suggests high pressure degassing.

\subsection{Origin of volcanic gas}

Large amounts of volcanic gases were discharged even after the sub-Plinian eruptions in January and the subsequent lava effusion in early February 2011 (Mori and Kato, 2013). The continuous volcanic gas emission, with a rate of 100-400 t/d SO $\mathrm{SO}_{2}$, after March 2011 amounts to a total $\mathrm{SO}_{2}$ emission of $7 \times 10^{4} \mathrm{t}$ in one year, which requires the degassing of $7 \times 10^{7} \mathrm{t}\left(3 \times 10^{7} \mathrm{~m}^{3}\right)$ of magma. The continuous volcanic gas emission requires a mechanism of degassing and gas transport from a large volume of magmas. Such persistent degassing is modeled by either the permeable gas flow model (Edmonds et al., 2003, 2010), or the conduit magma convection model (Kazahaya et al., 1994; Shinohara, 2008). The permeable gas flow model considers that the intensive and continuous gas emission is caused by the transport of volcanic gas exsolved at a deep and large magma chamber through a permeable volcanic conduit connecting the chamber to the surface (Edmonds et al., 2003, 2010). In such a case, volcanic gas compositions are likely be $\mathrm{CO}_{2}$-rich due to gas exsolution at high pressure. In contrast, the Shinmoedake volcanic gas is $\mathrm{H}_{2} \mathrm{O}$-rich (Fig. 8), which cannot be produced by highpressure degassing because the Shinmoedake magma is relatively $\mathrm{H}_{2} \mathrm{O}$-poor (Saito et al., 2011). The water content of the magmas is about $2 \mathrm{wt} . \%$ whose saturation pressure in an andesitic melt is $<50 \mathrm{MPa}$ at about $1000^{\circ} \mathrm{C}$ (Baker and Alletti, 2012). The magma chamber depth is estimated as about $10 \mathrm{~km}$ based on the crustal deformation before and after the eruptions measured by GPS (Nakao et al., 2011). As efficient $\mathrm{H}_{2} \mathrm{O}$ discharge can occur only at a low pressure, the intensive and continuous degassing at the Shinmoedake volcano cannot be caused by permeable gas flow from the magma chamber.

In the conduit magma convection model, degassing occurs under low pressure conditions at the top of the convecting magma column and the dense degassed magma descends through the magma column where a volatile-rich less dense magma ascends from a magma chamber to compensate the descending magma (Kazahaya et al., 1994; Shinohara, 2008). The low pressure degassing is consistent with the efficient $\mathrm{H}_{2} \mathrm{O}$ discharge from the $\mathrm{H}_{2} \mathrm{O}$-poor magma at Shinmoedake. In contrast, the S-poor composition of the volcanic gas and the variation of the $\mathrm{SO}_{2} / \mathrm{H}_{2} \mathrm{~S}$ ratio suggests that the degassing pressure of the Shinmoedake volcanic gases is higher than that at other persistently degassing volcanoes and changed with time (Figs. 7 and 8). However, quantitative evaluation of the degassing pressure for the S-poor composition is not possible due to the lack of the sulfur partition coefficient data.

We can evaluate the possible range of the degassing pressure variation based on the observed $\mathrm{H}_{2} \mathrm{O} / \mathrm{CO}_{2}$ ratio in the gas and the $\mathrm{H}_{2} \mathrm{O}$ content in melt inclusions, and $\mathrm{H}_{2} \mathrm{O}$ $\mathrm{CO}_{2}$ solubility in a silicate melt. The carbon dioxide content of the magma should less than $700 \mathrm{ppm}$, because the $\mathrm{H}_{2} \mathrm{O} / \mathrm{CO}_{2}$ mol ratio of the volcanic gas on May 18, 2011, is 70 and $\mathrm{H}_{2} \mathrm{O}$ content in the magma is $2 \mathrm{wt} . \%$ (Saito et al., 2011). If the $\mathrm{CO}_{2}$ content in the magma is $500 \mathrm{ppm}$, the degassing pressure to exsolve the gases with $\mathrm{H}_{2} \mathrm{O} / \mathrm{CO}_{2}=70$ is 3.0 MPa (Newman and Lowenstern, 2002). This calculation was conducted with solubility data for a rhyolitic melt at $900^{\circ} \mathrm{C}$, because a systematic $\mathrm{H}_{2} \mathrm{O}-\mathrm{CO}_{2}$ solubility dataset is not available for an andesitic melt, but the difference in the solubility is not large between rhyolitic and andesitic melts (Baker and Alletti, 2012). The ten times larger $\mathrm{SO}_{2} / \mathrm{H}_{2} \mathrm{~S}$ ratio on March 15 compared with that of May 18, 2011, suggests a ten times smaller degassing pressure. The degassing pressure change from $0.3 \mathrm{MPa}$ to 3.0 MPa corresponds to a depth change from 12 to $120 \mathrm{~m}$ under a lithostatic pressure gradient. The degassing pressure change will also cause a $\mathrm{H}_{2} \mathrm{O} / \mathrm{CO}_{2}$ ratio change in the exsolved gas phase from 100 to 70 . If the original $\mathrm{CO}_{2}$ content is $300 \mathrm{ppm}$, the degassing pressure on March 15 is $1.2 \mathrm{MPa}$ and that on May 18 is $12 \mathrm{MPa}$, corresponding to a depth change from 48 to $480 \mathrm{~m}$. Therefore the variation of the volcanic gas composition can be caused by changes of the degassing depth in the shallow part of the conduit system at $<500$-m depth.

The continuous degassing with the small composition variation at the Shinmoedake volcano during March 2011 is likely caused by the conduit magma convection with a variation of the degassing depth at the relatively shallow region. The intensive degassing started a few days prior to the sub-Plinian eruption which started on 26 January, 2011 (Kinoshita et al., 2011) and the $\mathrm{SO}_{2}$ flux quickly decreased from more than $10 \mathrm{kt} / \mathrm{d}$ at the end of January to less than 1,000 t/d in mid March 2011 (Mori and Kato, 2013). Since the intensive degassing continued even after lava effusion, the conduit magma convection process could have been established just after the end of the lava effusion activity. Small-scale Vulcanian eruptions were frequent in early February and the frequency and scale decreased with time. The last eruption occurred in September 2011, and since then the degassing continues without eruptive activity. Vulcanian eruptions with various frequencies are often observed at persistently degassing volcanoes of daciticandesitic magmas and the presence, or absence, of Vulcanian eruptions is attributed to slight changes in the conditions at the top of the convecting magma (Shinohara, 2008). Based on the conduit magma convection model, the relatively stable $\mathrm{SO}_{2}$ flux and gas composition indicate a stability of the magma plumbing and degassing conditions af- 
ter March 2011, and the absence of eruptive activity since September 2011 may not readily indicate a decrease of the eruptive potential of the volcano. The lava filling the summit crater is likely to be still molten in the interior and it is likely that the instability of the magma convection causes a drain back of the large volume of the accumulated lavas to the depth. In order to evaluate the stability of the magma convection, it is important to monitor the variation of the volcanic gas compositions.

\section{Summary}

Compositions of volcanic gases emitted from Shinmoedake during persistent degassing with repeating Vulcanian eruption were measured by the Multi-GAS mounted on the UAV and the Multi-GAS monitoring station. The UAV measurements were performed on March 15 and May 18, 2011; on March 15, only the $\mathrm{SO}_{2} / \mathrm{H}_{2} \mathrm{~S}$ ratio of the plume was quantified as 8 , and on May 18, the UAV flew through plumes with a maximum $\mathrm{SO}_{2}$ concentration of $2.5 \mathrm{ppm}$, and most of the major volcanic gas components were quantified as $\mathrm{CO}_{2} / \mathrm{SO}_{2}=8, \mathrm{SO}_{2} / \mathrm{H}_{2} \mathrm{~S}=0.8, \mathrm{H}_{2} \mathrm{O} / \mathrm{CO}_{2}=70$ and $\mathrm{H}_{2} / \mathrm{SO}_{2}=0.03$ (mol ratio). The Multi-GAS monitoring station was installed on April 12, 2011, about $5 \mathrm{~km}$ southeast of the crater and could occasionally detect diluted plumes with a maximum $\mathrm{SO}_{2}$ concentration of $0.22 \mathrm{ppm}$. Because of the low concentration of the plume, $\mathrm{SO}_{2} / \mathrm{H}_{2} \mathrm{~S}$ and $\mathrm{CO}_{2} / \mathrm{SO}_{2}$ ratios were obtained only 15 and 3 times during the one-year observation, respectively. The $\mathrm{SO}_{2} / \mathrm{H}_{2} \mathrm{~S}$ ratio gradually varied in a range from 0.8 to 3.3. The $\mathrm{CO}_{2} / \mathrm{SO}_{2}$ ratios were obtained in January and February 2012 as 12, which agrees with the ratio obtained on May 18 by the UAV measurement within the error. Combining the $\mathrm{SO}_{2} / \mathrm{H}_{2} \mathrm{~S}$ ratios obtained both by the UAV measurements and the monitoring station, the rapid decrease of the $\mathrm{SO}_{2} / \mathrm{H}_{2} \mathrm{~S}$ ratio from 8 on March 15 to 0.8 on May 18 was quantified.

The volcanic gas composition obtained on May 18, 2011, is S-poor compared with other intensively degassing volcanoes, such as Satsuma-Iwojima or Miyakejima. Comparison with the melt inclusion volatile contents and their solubility, the S-poor composition is attributed to high-pressure degassing and contamination of meteoric water. The decrease of the $\mathrm{SO}_{2} / \mathrm{H}_{2} \mathrm{~S}$ ratio from March 15 to May 18 is likely due to a ten times increase of the degassing pressure, which agrees with the high-pressure degassing suggested by the S-poor composition on May 18, 2011. The $\mathrm{H}_{2} \mathrm{O}$-poor composition of the Shinmoedake magmas, however, requires a maximum degassing pressure less than 1.2 $\mathrm{MPa}(<500-\mathrm{m}$ depth), implying that the degassing pressure variation should occur at the shallow region of the magma plumbing system. Based on the $\mathrm{SO}_{2}$ fluxes and the gas compositions, the conduit magma convection is considered as the gas supply mechanism at Shinmoedake, and the degassing pressure change is attributed to the change of depth of the convecting magma column top. The stable gas composition after May 18 suggests a stable condition of the conduit magma convection, although the eruption frequency decreased with time.

Acknowledgments. I would like to thank Drs. I. Miyagi and A.
Tanaka for their assistance during the UAV measurements, Dr. T. Mori for his assistance to estimate the plume direction during the UAV measurements by COMPUSS measurements, Dr. G. Saito for discussion on the volatile contents in magmas, the journal editor, Dr. M. Ichihara for the careful editing and two anonymous reviewers for constructive reviews. This study is supported by the Ministry of Education, Culture, Sports, Science and Technology of the Japanese Government under the program of Special Coordination Funds for Promoting Science and Technology, "Urgent Study on the Eruption of Mt. Shinmoe-dake, Kirishima, 2011".

\section{References}

Aiuppa, A., C. Federico, G. Giudice, and S. Gurrieri, Chemical mapping of a fumarolic field: La Fossa Crater, Vulcano Island (Aeolian Islands, Italy), Geophys. Res. Lett., 32, L13309, doi:10.1029/2005GL023207, 2005

Aiuppa, A., C. Federico, G. Giudice, G. Giuffrida, R. Guida, S. Gurrieri, M. Liuzzo, R. Moretti, and P. Papale, The 2007 eruption of Stromboli volcano: Insights from real-time measurement of the volcanic gas plume $\mathrm{CO}_{2} / \mathrm{SO}_{2}$ ratio, J. Volcanol. Geotherm. Res., 182, 221-230, 2009.

Allard, P., M. Burton, and F. Mure, Spectroscopic evidence for a lava fountain driven by previously accumulated magmatic gas, Nature, 433, 407-410, 2005.

Baker, D. R. and M. Alletti, Fluid saturation and volatile partitioning between melts and hydrous fluids in crustal magmatic systems: The contribution of experiments and solubility models, Earth Sci. Rev., 114, 298-324, 2012.

Edmonds, M., C. Oppenheimer, D. M. Pyle, R. A. Herd, and G. Thompson, $\mathrm{SO}_{2}$ emissions from Soufriére Hills volcano and their relationship to conduit permeability, hydrothermal interaction and degassing regime, $J$. Volcanol. Geotherm. Res., 124, 23-43, 2003.

Edmonds, M., A. Aiuppa, M. Humphreys, R. Moretti, G. Giudice, R. S. Martin, R. A. Herd, and T. Christopher, Excess volatiles supplied by mingling of mafic magma at an andesite arc volcano, Geochem. Geophys. Geosyst., 11, Q04005, doi:10.1029/2009GC002781, 2010.

Furukawa, R., N. Geshi, T. Oikawa, T. Chiba, S. Nakada, and M. Nagai, Pyroclastic fall deposit and eruptive mass of 2011 eruption from Shinmoedake Volcano, Kirishima Volcanic Group Japan Geosci. Union Meeting Abstract, SVC, 50, 36, 2012.

Gerlach, T. M., H. Delgado, K. A. McGee, M. P. Doukas, J. J. Venegas, and L. Cárdenas, Application of the LI-COR $\mathrm{CO}_{2}$ analyzer to volcanic plumes: A case study, volcán Popocatépetl, Mexico, June 7 and 10, 1995, J. Geophys. Res., 102(B4), 8005-8019, doi:10.1029/96JB03887, 1997.

Giggenbach, W. F., Redox processes governing the chemistry of fumarolic gas discharges from White Island, New Zealand. Appl. Geochem., 2, 143-161, 1987.

Giggenbach, W. F., Chemical composition of volcanic gases, in Monitoring and Mitigation of Volcanic Hazards, edited by R. Scarpa and R. I. Tilling, 21-256, Springer Verlag, Berlin-Heidelberg, 1996.

Giggenbach, W. F. and S. Matsuo, Evaluation of results from second and Third IAVCEI Field Workshop on Volcanic Gases, Mt. Usu, Japan and White Island, New Zealand. Appl. Geochem., 6, 125-141, 1991.

Imura, R. and T. Kobayashi, Geological map of Kirishima volcano (1:25,000), Geological Map of Volcanoes, 11, Geological Survey of Japan, AIST, 2001 (in Japanese with English abstract).

Kazahaya, K., H. Shinohara, and G. Saito, Excessive degassing of IzuOshima volcano: Magma convection in a conduit, Bull. Volcanol., 56, 207-216, 1994.

Kinoshita, K., N. Iino, C. Kanagaki, I. Harada, J. Park, and M. Sakamoto, Ground observation and satellite image analysis of eruption clouds at Kirishima-Shinmoedake volcano, Japan Geosci. Union Meeting Abstract, SVC070-P16, 2011.

Lense, P., S. C. Kohn, F. Witham, R. E. Botcharnikov, and H. Behrens, Experimental simulation of closed-system degassing in the system basalt$\mathrm{H}_{2}-\mathrm{CO}_{2}-\mathrm{S}-\mathrm{Cl}$, J. Petrol., 52, 1737-1762, 2011.

Lin, P. H., Observations: The first successful typhoon eyewall penetration reconnaissance flight mission conducted by the unmanned aerial vehicle, Aerosonde, Bull. Am. Meteorol. Soc., 87, 1481-1483, doi:10.1175/BAMS-87-11-1481, 2006.

Matsuo, S., On the origin of volcanic gases, J. Earth Sci. Nagoya Univ., 8 , 222-245, 1960.

McGonigle, A. J. S., A. Aiuppa, G. Giudice, G. Tamburello, A. J. Hodson, and S. Gurrieri, Unmanned aerial vehicle measurements of 
volcanic carbon dioxide fluxes, Geophys. Res. Lett., 35, L06303, doi:10.1029/2007GL032508, 2008.

Miyagi, Y., ALOS observations of 2011 eruption of Shimoe-dake, Program Abstract Volcanol. Soc. Japan 2011 Fall Meeting, 14, 2011.

Mizutani, T. and T. Sugiura, Variations in chemical and isotopic compositions of fumarolic gases from Showashinzan volcano, Hokkaido, Japan, Geochem. J., 16, 63-71, 1982.

Mori, T. and K. Kato, Sulfur dioxide emissions during the 2011 eruption of Shinmoedake volcano, Japan, Earth Planets Space, 65, this issue, 573-580, doi:10.5047/eps.2013.04.005, 2013.

Mori, T., J. Hirabayashi, K. Kazahaya, T. Mori, M. Ohwada, M. Miyashita, H. Iino, and Y. Nakahori, A compact ultraviolet spectrometer system (COMPUSS) for monitoring volcanic $\mathrm{SO}_{2}$ emission: Validation and preliminary observation, Bull. Volcanol. Soc. Jpn., 52, 105-112, 2007.

Nakao, S., Y. Morita, K. Gotou, H. Yakiwara, S. Hirano, J. Oikawa, H. Ueda, T. Kozono, Y. Hirata, H. Takahashi, M. Ichiyanagi, Y. Ohta, T. Matsushima, and M. Iguchi, Crustal deformation before and after eruption on Jan. 26, 2011 in Kirishima Shinmoedake, Japan, Program Abstract Volcanol. Soc. Japan 2011 Fall Meeting, 27, 2011.

Newman, S. and J. B. Lowenstern, VOLATILECALC: A silicate melt-H ${ }_{2}-$ $\mathrm{CO}_{2}$ solution model written in Visual Basic Excel, Comput. Geosci., 2, 597-604, 2002.

Ohba, T., J. Hirabayashi, and M. Yoshida, Equilibrium temperature and redox state of volcanic gas at Unzen volcano, Japan, J. Volcanol. Geotherm. Res., 60, 263-272, 1994.

Oppenheimer, C., P. Bani, J. A. Calkins, M. R. Burton, and G. M. Sawyer, Rapid FTIR sensing of volcanic gases released by Strombolian explosions at Yasur volcano, Vanuatu. Appl. Phys., B 85, 453-460, 2006.

Saito, G., K. Kazahaya, H. Shinohara, J. Stimac, and Y. Kawanabe, Variation of volatile concentration in a magma system of Satsuma-Iwojima volcano deduced from melt inclusion analyses, J. Volcanol. Geotherm. Res., 108, 11-31, 2001.

Saito, G., Y. Morishita, and H. Shinohara, Magma plumbing system of the 2000 eruption of Miyakejima volcano, Japan, deduced from volatile and major component contents of olivine-hosted melt inclusions, $J$. Geophys. Res., 115, doi:10.1029/2010JB007433, 2010.

Saito, G., N. Geshi, and H. Shinohara, Magma mixing and degassing processes of Kirishima 2011 eruption based on chemical analyses of minerals an melt inclusions, Program Abstract Volcanol. Soc. Japan 2011 Fall Meeting, p. 30, 2011.

Shinohara, H., A new technique to estimate volcanic gas composition:
Plume measurements with a portable multi-sensor system, J. Volcanol. Geotherm. Res., 143, 319-333, 2005.

Shinohara, H., Excess degassing from volcanoes and its role on eruptive and intrusive activity, Rev. Geophys., 46, RG4005, doi:10.1029/2007RG000244, 2008.

Shinohara, H., K. Kazahaya, G. Saito, N. Matsushima, and Y. Kawanabe, Degassing activity from Iwodake rhyolitic cone, Satsuma-Iwojima volcano, Japan: Formation of a new degassing vent, 1990-1999, Earth Planets Space, 54, 175-185, 2002.

Shinohara, H., K. Kazahaya, G. Saito, K. Fukui, and M. Odai, Variation of $\mathrm{CO}_{2} / \mathrm{SO}_{2}$ ratio in volcanic plumes of Miyakejima: Stable degassing deduced from heliborne measurements, Geophys. Res. Lett., 30(23), doi:10.1029/2002GL016105, 2003a.

Shinohara, H., K. Fukui, K. Kazahaya, and G. Saito, Degassing process of Miyakejima volcano: Implications of gas emission rate and melt inclusion data, in Advances in Volcanology Vol. 4, edited by B. de Vivo and B. Bodnar, 147-161, Melt Inclusion s in Volcanic Systems, Elsevier, 2003 b.

Shinohara, H., N. Matsushima, K. Kazahaya, and M. Ohwada, Magmahydrothermal system interaction inferred from volcanic gas measurements obtained during 2003-2008 at Meakandake volcano, Hokkaido, Japan, Bull. Volcanol., 73, 409-421, 2011.

Symonds, R. B., Y. Mizutani, and P. H. Briggs, Long-term geochemical surveillance of fumaroles at Showa-Shinzan dome, Usu volcano, Japan, J. Volcanol. Geotherm. Res., 73, 177-221, 1996.

Taran, Y., J. W. Hedenquist, and M. A. Korzhinsky, Tkachenko SI, Shmulovich KI Geochemistry of magmatic gases from Kudryavy volcano, Iturup, Kuril Islands, Geochim. Cosmochim. Acta, 59, 1749-1761, 1995.

Watai, T., T. Machida, N. Ishizaki, and G. Inoue, A lightweight observation system for atmospheric carbon dioxide concentration using a small unmanned aerial vehicle, J. Atmos. Oceanic Technol., 23, 700710, doi:10.1175/JTECH1866.1, 2006.

Webster, J. D. and R. E. Botcharnikov, Distribution of sulfur between melt and fluid in S-O-H-C-Cl-bearing magmatic systems at shallow crustal pressures and temperatures, Rev. Mineral. Geochem., 73, 247$283,2011$.

H. Shinohara (e-mail: shinohara-h@aist.go.jp) 